\title{
From the Physical to the Fiscal: Monetizing the Poor
}

\author{
Mark Covaleski ${ }^{1}$, Mark Dirsmith ${ }^{2}$, Sajay Samuel ${ }^{2} \&$ Jane Weiss $^{3}$ \\ ${ }^{1}$ Graduate School of Business, University of Wisconsin, Madison Wisconsin, USA \\ ${ }^{2}$ Smeal College of Business, Pennsylvania State University, University Park Pennsylvania, USA \\ ${ }^{3}$ College of Business, University of Idaho, Moscow Idaho, USA \\ Correspondence: Mark Dirsmith, Smeal College of Business, Pennsylvania State University, University Park \\ Pennsylvania, USA. E-mail: eu3@psu.edu
}

Received: July 23, $2013 \quad$ Accepted: November 11, $2013 \quad$ Online Published: April 29, 2014
doi:10.5539/par.v3n1p1
URL: http://dx.doi.org/10.5539/par.v3n1p1

\begin{abstract}
One effect of the deteriorating fiscal condition of governments is the effort to "reform" the "welfare state." Often expressed using the rubrics of the New Public Management (NPM) and Public/Private Partnerships (PPP), a significant component of this effort is harmonious with a neo-liberal ideology incorporating commercial business practices into public sector organizations, which has been allied with the financialization of government, the capitation of welfare recipients and asset-based welfare. We examine the transformation of public entities into quasi-commercial ones by first contextualizing the rise of NPM, PPP, financialization, capitation and asset-based welfare within the historical evolution of incorporating business practices into government. And second, we examine the processes by which the State of Wisconsin replaced the forty year old AFDC (Aid to Families with Dependent Children) program with a new $W-2$ (Welfare Works) welfare reform program. Finally, we explore implications.
\end{abstract}

Keywords: welfare reform, welfare works, new public management, public/private partnerships, financialization, neo-liberal ideology, capitation, asset-based welfare

\section{Introduction}

Welfare has long enjoyed, and suffered from, considerable attention from politicians, the press, the business community and the public. Moreover, considerable money has been spent and misspent in providing support to the needy (Meyers, 2003; Quadagno, 1994; Riccucci, 2005). Described by New York state budget director Peter Goldberg as being "hated by those administer it, mistrusted by those who pay for it and held in contempt by those who receive it," it is not surprising that major efforts have long been directed at reforming welfare. Traditionally within the United States, under the Aid to Families with Dependent Children (AFDC) welfare system, states were funded by a federal/state matching arrangement, with open-ended funding and no ceiling as to the amount funded. The size of the entitlement awarded to primarily single mothers was not directly controllable since it was based on how many people qualified for the assistance: "With the former [welfare] plan being entitlement, accountability was not a concern. Agencies did not have performance criteria to achieve" (Wildavsky, 1975: 124).Welfare programs, however, are strongly influenced by political climate (Piven \& Cloward, 1993; Riccucci, 2005; Hausermann \& Palier, 2008; Howard, 1997; Soss, Fording \& Schram, 2011; Covaleski, Dirsmith \& Weiss, 2012). King (1992: 222), for example, concluded that there exists a generally negative sentiment towards "benefits for the undeserved" even though they represent a small percentage of the Federal government's expenditures as reflected in President Ronald Reagan's Fourth of July speech that proclaimed "We Americans do not get together to celebrate Dependence Day” (Heclo, 1986: 182-183; Gilbert, 2009; Misra, Moller \& Karides, 2003).

In contrast, contemporary, employment-based welfare reform, sometimes referred to as Welfare Works or W-2, championed by such states as Wisconsin, California and New York beginning in the 1980's and 90's (Soss, et al., 2011), represents "another lurch toward pushing the poor to take responsibility for their circumstances, with an offer of government aid to reward those who did" (Wall Street Journal, 2006: A10). Wisconsin's development and implementation of the W-2 welfare reform program has served as a prominent model for international welfare reform:

Just as communists, radicals and progressives traveled to Moscow in the 1920s to see socialism being built in one country, so are politicians, policy analysts and journalists today arriving in 
Wisconsin to see the welfare state being dismantled. $B B C$, the London Observer and leading Japanese papers have all sent correspondents. So have most major American news organizations (Massing, 1999: 9; see also, Wisconsin State Journal, 9/02/01: B1, B6, B7; for its impact on Ontario, Canada, see Statistics, Canada, 2007; T. D. Bank Financial Group, 2005; for impact in the U.K., see United Kingdom Department of Works and Pensions, 2011).

The W-2 reform effort is harmonious with the "New Public Management" reform movements, wherein economically rational improvements in governance are sought by bringing together state and local governments with business enterprises that is closely associated with "Public-Private Partnerships" (PPP's) internationally (English \& Skellern, 2007; Mathiasen, 1997). Borne of burgeoning public sector debt and inefficient operations in the 1970's, English and Skellern (2007: 4) observed that these approaches are based on two theoretical foundations: (1) the adoption of such private sector management techniques as performance measures and incentive systems at the micro level by emphasizing the "three e's" of economy, efficiency and effectiveness, and (2) the exposure of government services to market forces at the macro level by transforming government from a provider to a purchaser of public services through outsourcing activities to and entering into partnerships with the private sector (see also Hood, 1995). This movement is more generally harmonious with the financialization of the global economy which emphasizes economic incentives, financing technologies, financial markets and its institutions in reforming and operating governmental units in which competitive markets dynamically shape the behavior of not only private sector corporations, but also governments and individuals in propagating a "new spirit of capitalism" (c. f., Davis, 2009; Epstein, 2005; Finlayson, 2009; Foster, 2007; Krippner, 2005, 2010).

The purpose of this article is to closely examine how governmental operations were reformed under the aegis of NPM/PPP generally, and in particular the transformation of welfare systems in Wisconsin by W-2, as well as to briefly describe the effects of this reform effort on the object of their concerns. As such, it adds to evidence as to whether "industrial welfare states can be reformed in an employment-friendly way and what are the conditions for the implementation of unpopular 'commodifying' [or in our terms, monetizing] reforms?" (Hausermann \& Palier, 2008: 560) by examining the dynamics by which such a reform was undertaken as well as its consequences. The remainder of this paper is organized into three sections. In section two, the historical incorporation of business practices into government, and the rise of NPM, PPP, financialization and neo-liberal ideology are briefly sketched within the first movement. Section three describes our analysis of the development and implementation of Wisconsin's W-2. Section four uses recently emerging evidence concerning the impact of deteriorating economic conditions on the poor in order to explore implications emanating from our analysis and the confounding effects of what has come to be known as asset-based welfare. And finally, section five offers concluding remarks concerning such illusory auto-regulatory mechanisms as W-2.

\section{The Historical and Institutional Foundations of W-2}

A business-like approach to public administration focused on efficiency, effectiveness and outcomes, has been the staple of attempts to reform every level of the US government since the turn of the last century (McCaffery, 1987). Perhaps the largest, whole scale incorporation of business practices into governmental operations took place during the progressive era, roughly 1900 to 1916. Progressivism fosters the rise of a scientifically based approach to administrating public resources. Rational bureaucratic administration, reliant preferably on numerical facts managed by civil servants not beholden to political parties and tuned to the public interest, was thought necessary to temper and channel the the pernicious influence of politics and big business and to permit informed judgments by both administrators. The progressive philosophy envisioned the state as a neutral instrument of reform, and many activities that had once been the concern only of those directly involved, such as local governments, would be transferred to higher levels of government (Larson, 1977: 137-158). It was reasoned that overcoming the wide-spread and adverse consequences of industrialism and entrenched business interests could only be achieved if the power of the state, guided by intelligence, reason, and the ideology of scientific management, was the basis for rational public administration (Kolko, 1963).

The label of "progressive" has, however, been increasingly reinterpreted as actually being a triumph of conservatism in the sense that there was pervasive penetration by the business community into governmental affairs in order to preserve the social, political, and economic relations essential to a capitalist society (Kolko, 1963: 1-9; Covaleski \& Dirsmith, 1991). Reflected in this view is a merging of the economic and the political, in which stability and predictability are engendered by applying the logic of economic calculus to political endeavor. For Kolko (1963: 1-24), organizational control over politics was embedded in and facilitated by the rationality and allied techniques imported to government from business. Political rationalization vis-a-vis economic rationalization became the means of attaining both order in the economic sphere and security in the political arena. Rationalized administrative policies and practices did not merely emerge as a consequence of 
widespread concern for operational efficiency, but also as an artifact of the power nexus linking economic and political spheres of influence. Hays (1959: 17-22) further suggested that the progressive movement sheds light not so much on the content of public policy, but rather on the nature of the resulting political structure and human interactions peculiar to that political structure. Progressivism represented more than just the legitimization of a calculation-based form of decision-making by also supporting a transfer of power toward a mono-centric base (Wilson, 1956: 169).

Robert M. LaFollette, turn of the twentieth century Wisconsin Governor, U.S. Senator and Presidential candidate, and the state of Wisconsin played especially prominent roles in the development of the progressive movement (Kolko, 1963; Larson, 1977). Wisconsin inaugurated a comprehensive program of political, economic, and social reforms that affected the life of virtually every person in the state and served as a model that was copied by many other states and the federal government. As Maxwell (1956: 8-9) argued: "The program developed in Wisconsin was distinguished from the reforms of other states chiefly in that it was more comprehensive and far-reaching rather than more radical." Social concepts such as workmen's compensation, Social Security, utility and industrial regulation, and unemployment insurance were initiated under LaFollette's leadership.

And yet, by the late 1940s, the distinction between politics and administration that animated Progressivism was seen to be both empirically naïve and scientifically untenable. Herbert Simon (1947) denigrated the "principles of administration" as mere folksy proverbs and economist Kenneth Arrow (1970) cast severe mathematical doubt on the very possibility of a "public good" or the "public interest;" and administrators were understood to be making political decisions instead of merely serving as the neutral executors of congressional laws.

Nevertheless, the practical distinctions between politics and administration still serve as foundations for the use and spread of the calculative practices throughout government. Though contested, calculative regimes routinely fail, but nevertheless this failure is usually offered as a justification to further re-engineer and deepen the range and scope of calculative techniques. It would seem that the failure of governmental reforms to achieve their stated goals is met by calls to further enhance their technical details while adjusting related budget appropriations. In part, it is this dynamic that continues to fuel the growth of metrics of accountability and performance in the governmental sector. Their intensity and range are being steadily ratcheted up. Consequently, the expansion of the "administrative state," articulated into administrative law and into attendant methods of calculation, continues unabated.

Within the emergence of the administrative state, the judgments of government bureaucrats were transformed into variables in a production process in which bureaucrats and the citizenry were transformed into "calculable selves" (Miller, 1992); the incommensurable were rendered into the commensurable as widely different social phenomena were measured using common metrics (Espelend \& Stevens, 1998). Perhaps the capacity of financial categories to encode human needs derives from the fact that money is the purest abstraction (Simmel, 1990). The relative asymmetry of financial and welfare service abstractions permits state politicians and administrative cadre to continuously transform such areas as welfare service practices into economic categories. The capacity of business and financial categories to asymmetrically calibrate public administrative practices in terms of "products" (e.g., welfare recipients placed in jobs) and their costs, is perhaps the thin wedge that transforms public service practices into business processes.

This transformation is accomplished based on two central ideas: humans being defined as assets, and human behavior modification using incentives. Concerning the first idea, welfare recipients under AFDC were re-categorized from "needy persons" into "liabilities" that are to be converted into "assets" in the sense that they were to be placed in the workforce and hopefully would generate economic benefits. Through both theoretical and empirical work since the mid-century, the notion that people are assets has been made plausible within economics. Seeking an answer to the question of "what is the contribution of changes in the quality of people to economic growth?" the theory of human capital sought to optimize the rate of return on living assets (Becker, 1993). The aim of improving the effectiveness of people demanded a careful consideration of the costs and benefits of welfare programs as an investment in human capital, wherein it was not only recognized that different "asset classes" of humans yielded different "returns on investment," but also that these returns could be augmented through further education and improved health of low yield assets. A corresponding statistical metric that may be applied to evaluating the level of "human development" of a nation or state is the Human Development Index (HDI).

Concerning the second idea, incentives, Arrow reasoned that "action cannot be commanded," and insisted that behavior could and had to be modified through an indirect "system of rules, organizational structures, performance measures, and penalties and rewards" (1970: 146). Accordingly, he underscored the centrality for 
incentives to indirectly harness independent people together while preserving the appearance of their independence. He suggested that incentives of a usually financial nature can engender decentralized action in conformity with centrally orchestrated plans (c. f., Preston, Chua \& Neu, 1997). In the context of healthcare, for example, his work was taken up to recommend "an organized system financed on a prepaid or capitation basis" so as to indirectly influence the professional judgment of physicians. Here, a physician is paid a fixed amount for each person they are assigned to treat based upon the average expected cost of treatment across patents; thus, physicians are economically motivated to avoid high cost treatments, and also avoid high treatment cost patients through strategic screening, and pursue such low cost treatment strategies as preventative care. As we shall see, Wisconsin sought to directly mimic the capitation calculative practice used in its healthcare program in reforming its welfare program. The hope was that if such a capitation metric was garnished with the carrot and stick of bonuses and penalties for surpluses and shortfalls respectively, welfare agency staff would act as self-interested suppliers who keep costs to a minimum --their judgments would be modified by knowledge of their fiscal consequences. The scheme of welfare appropriations would be given its now familiar theoretical justification in the language of risk and incentives to hasten "economic competition" between public agencies and private vendors in public/private partnerships (PPP's), and among private vendors bidding on contracts.

Beginning in the 1990's, sustained attention has been directed toward transforming government into quasi-market entities (Hood, 1995). Accordingly, a new accent on such "administrative technologies as customer service, performance-based contracting, competition, market incentives and deregulation" began to be promoted under the rubric of the "new public management" (Denhardt \& Baker, 2007: 139). It was during this period that "reinventing government" became a slogan animating the widespread reform of government entities (Osborne \& Gaebler, 1992); that a raft of laws such as the Chief Financial Officers Act (1990), the Government Performance and Results Act (1993) and the GASB's Statement 34 (1999) requiring balance-sheets and quasi-income statements from local, state and federal governments, were passed in the U.S. to foster increased accountability and results-based management in government operations; and that the language of managerialism and economic rationalism would be widely applied to government programs (Kettl, 2002a). In turn, NPM has been applied to reforming public employment services (e.g., W-2 in Wisconsin) thereby fundamentally transforming them.

Arguably, the effort to make government organizations more market-like through accountability and performance metrics, and linking the public and private sectors through NPM/PPP, is closely linked to the emerging phenomenon of the " hollow state" (Milward, 1996) ostensibly favored by a neo-liberal ideology. Within this ideological system, focus is placed on engendering free and open markets characterized by an ethos of competition unfettered by government regulation in which the size of government and its direct spending are minimized (Amable, 2011; Campbell, 2010; Crouch, 2011; Clarke, 2004; Mudge, 2008). Here, Ferraro, Pfeffer and Sutton (2005: 11) observed that "market-based exchanges are considered to be the baseline and the natural and the best option for organizing activity," so much so that such notions as "the market" are not just ideologies, but may themselves have become institutionalized. The growing separation between the sources and uses of public funds lies at the heart of this phenomenon. Whether under the banner of "privatization," "contracting out," or "outsourcing," publicly-funded services are increasingly provided by the private and non-profit sectors. Since the mid-twentieth century, every major government service in the US has relied on "public-private partnerships." Fortified by a vast toolkit imported from business, this hollowing out is not a feature limited to the federal government, but rather effects all levels of government. Already "by the mid-1980s, the average American city contracted out $23 \%$ of its 64 common municipal services to the private sector, whereas the average American state contracted out $14 \%$ of its activities ... Between 1982 and 1992 contracting out increased by $121 \%$ in the 596 cities where comparable data were available" (Prizza, 2003: 318). "Direct government," understood as the delivery of public services through public employees, in turn, accounts for only $5 \%$ of total government expenditures. Even when such items as interest payments, income transfers and direct payments are included within the category of direct government expenditures, third party delivery of services still accounts for $78 \%$ of total government expenditures (Kettl, 2002b: 4). Accordingly, the precise sense in which one can still speak of "big government" remains an open question in a time when governments function as monetary conduits channeling money to the private sector. In this light, the concern for emasculating public sector unions, such as is occurring in Wisconsin (Washington Post, 2012), seems more symbolic and political than substantive in terms of reducing governmental spending. Consequently, the private spending of public funds, in turn, further fuels increased need for measures of accountability and performance, far more than what may be required in regimes of direct government.

Research on NPM/PPP has primarily focused on examining the differences and variations in implementation. Recent research has focused on examining the unintended consequences, perverse effects and paradoxes of 
NPM/PPP reforms. For example, research has probed the "production paradox" according to which "the basic control routines associated with contemporary public management involves more intensive specification of outputs, encapsulated in performance contracts and indicators" (Hood \& Peters, 2004: 270). Since some governmental activities are neither easily observable nor measurable, the imposition of performance and outcome metrics generate unintended effects, notably gaming (Dunleavy, Margetts, Bastow \& Tinkler, 2006; Covaleski \& Dirsmith, 2005). Cooper and Hopper (2007), for example, explored NPM in the context of the fiscal crisis of the state and concluded it is part of a more general effort to commercialize arenas of life previously kept outside the logic of economic rationalization; they revealed complex interests that need to be stitched together with calculative technologies and rationales in order to effect change. The failure to account for context can be fatal, as suggested by Chwastiak (2001), who demonstrates that such calculative techniques have been deployed to normalize even issues of war and death by transforming moral questions into technical questions of resource allocation.

Although NPM/PPP's derivative, $W-2$, may be understood as a "financing mechanism," a "method of regulation", and even an "accounting technology", it was originally devised as a tool of social engineering directed at "moving the poor along the self-sufficiency continuum" and redefining them from being welfare recipients to employed (albeit often marginally) workers. Welfare service delivery agents, in turn, were redefined from being "eligibility technicians" to "employment planners" driven by "organizational imperatives." The obvious, if troubling, question arises here of the ethical implications of transforming welfare services into a commodity. Calculative techniques implicit in such NPM/PPP W-2 elements as performance contracting "function as a technology of distributive government" that make "life and death decisions inherent in rationing invisible" (Preston, et al., 1997: 161). The poverty of people is no longer viewed as a human problem, but increasingly as a "budget deficit problem" (Cox, 1998). It is in this vein that the ideology applied to delivering welfare services may be seen as having become "financialized" (Finlayson, 2009; Krippner, 2005, 2010), and welfare recipients having become monetized and transformed from physical into fiscal bodies.

\section{Wisconsin's W-2 Program and Transforming the Physical into the Fiscal}

AFDC, W-2's predecessor, was created as part of the Social Security Act in 1935, and was the primary Federal program providing cash assistance to single parents (predominantly mothers; DeParle, 2004) and their dependent children, hence its title Aid for Families with Dependent Children. The AFDC program was jointly administered and funded by the Federal and state governments. As a condition of receiving Federal funds, states had to have their $A F D C$ programs approved by the Federal government and strictly adhere to certain requirements. For example, states were required to administer their programs solely through government agencies, and though Wisconsin's state employees did not run the program on a day-to-day basis, they delegated the task to the social service agency employees of the 72 counties. The AFDC matching grant program relied on a cost-plus reimbursement system, wherein the county agencies were reimbursed for the costs they incurred, a formula that imposed no restrictions on the number of recipients or costs. The counties accrued expenses by paying benefits to their $A F D C$ clients and offering them services. The State was obligated by law to reimburse those expenses, no matter what kind of results the county was producing in terms of, for example, reducing poverty, reducing social dependency, and moving recipients into employment.

With a budget of $\$ 652$ million and serving 300,000 single parents and their families, the $A F D C$-based welfare system was decried by politicians for being too expensive and fostering a culture of dependence (for discussion internationally, see Hausermann \& Palier, 2008). Consistent with this "culture of dependence, criticisms of the time included positions that it encouraged unwed motherhood, acted as a disincentive to marriage, contributed to divorce and motivated the poor to have more children. For example, Nobel Laureate William Shockley (in Shurkin, 2006 ) advanced a controversial theory that AFDC motivated the poor, who were therefore less educated and less productive members of society, especially African Americans, to have more children, thereby leading to a dysgenic effect (reverse evolution). Murray (1984) ismilarly reasonedthat AFDC caused dependency in that it was economically rational for more people to quit working and go on welfare. Although empirical evidence is sparse supporting these criticisms, the U. S. Department of Health and Human Services (2009) conducted surveys in 1993 and 2006 and found that the co-habitation/marriage incentives of female recipients are influenced by welfare regulations and suggest disincentives to marry the fathers of their children. Reflecting a darker interpretation, Suddaby (2010: 17; Misra, Moller \& Karides, 2003; Quadagno, 1994) observed that political strategists of this era undertook systematic campaigns to de-institutionalize welfare:

Under the Johnson presidency the word [welfare] was considered to be a favorable one by Americans of all political stripes. After a concerted campaign by Republican strategists, who identified and publicly exposed a series of serious abuses of the welfare system, terming these 
abusers "welfare queens," the term [welfare] was systematically de-legitimated and has since disappeared from political discourse in the United States.

As a result, Republican Governor Tommy Thompson actively negotiated with the Federal Health and Human Services $(H H S)$ to obtain waivers under AFDC's Section 1115 to try alternative approaches to welfare in exchange for a promised reduction of welfare expenditures. Authorized to begin experimenting with $A F D C$, Wisconsin subsequently applied its own version of the JOBS program as well as other efforts (Katz, 2001: 94-98). Labeled as the "Work First" program, this market-based, performance contract approach allowed State officials to contract with different counties, and, for the first time, for-profit vendors throughout the State.

Milwaukee County generally performed poorly in $J O B S$ by not enforcing enrollment and job search as effectively as did other jurisdictions. Most of the payments from the State to the county agencies were based upon a cost-plus reimbursement basis for the caseload that each agency handled. But, beginning in 1994, some of the contract payments were withheld from Milwaukee County, and a performance pool was instead set aside that could only be earned if the Milwaukee's agencies placed welfare recipients in jobs, and thus the agencies were redefined from being "eligibility technicians" to "employment planners." As a result of installing this incentive system, job placements increased by over $30 \%$ in the first 6 months of 1994 in Milwaukee County. Because of this success, the State expanded JOBS performance contracting to all the other counties in 1995, with a portion of their contracts being withheld and subject to de facto performance-based contracts. This performance-based contracting was further ratcheted up and the performance pool increased, so that, by 1997, the JOBS providers throughout the State had to earn virtually all of their contract payments on a performance basis.

Concurrent with JOBS' success, in December, 1993 Governor Thompson signed legislation ending Wisconsin's participation in $A F D C$ by January 1, 1999 and assembled the "99 Group," whose job was to develop $W-2$ and overhaul Wisconsin's welfare program. A major, codified innovation implemented within $W-2$ by the 99 Group was performance-based contracting. The intent of the performance-based contract was to make $W-2$ operations less defined by bureaucratic rules and more defined by the forces of self-interest and market forces on the part of State as budgeter and the provider agencies as budgetees. Here, the delivery agency would receive performance incentives for focusing on intended outputs of the program: assisting participants to move up the "self-sufficiency continuum" through un-subsidized employment (Department of Workforce Development, DWD, 2000). Performance-based contracting would encourage counties to be accountable for outcomes instead of process by pegging vendor rewards to the outcomes Wisconsin wanted to achieve, without much detail on required procedures. Such an approach would give public assistance administrators a financial stake in the outcomes they produced.

The 99 Group issued a working draft of the $W-2$ program in 1995, proposing a strong privatization thrust, and a related competitive bid process $(C B P)$ that was subsequently leaked in advance of its formal issuance. County workers, reinforced by their unions, bitterly criticized this $1995 \mathrm{draft}$ as undermining their ability to serve the poor. Grass-roots political actors from the counties lobbied the State Assembly and Senate, making it clear that the counties wanted to continue administering welfare services under $W-2$. The 99 Group, in turn, realized $W-2$ would be too costly to run if the caseloads did not decrease significantly in the remaining two years before $W-2$ was formally phased in, and feared that unionized county workers might protest by not continuing to reduce caseloads. The 99 Group subsequently compromised and opened the definition of "market-delivery welfare system" to negotiation with the counties.

After negotiations, the 99 Group launched $W-2$ with caseload reduction targets for the counties to meet between September 1, 1995 and August 30, 1996. In exchange for the requisite grass roots support, if a county provider met those targets, it would earn the "right of first selection" (ROFS) for the first $W-2$ contract period; a county would qualify automatically to be the $W-2$ vendor if it met the target, without any competition from private vendors. If a pre-existing county agency did not qualify to become a $W-2$ provider, a competitive bid proposal process $(C B P)$ would then be used to determine the new service provider. Importantly, the ROFS criteria were designed to eliminate counties (i.e., particularly Milwaukee County that had failed during the $A F D C / J O B S$ regime) that could not perform at the level needed to make $W$-2 work, and to include those that could. With Milwaukee County having $65 \%$ of the State's welfare caseload and costs, the County's non-participation in the CBP process was strategically important to the successful implementation of $W-2$. The State's position can be seen as early as 1993 when the Government Operations Act amended the initial $W$-2 statute with some tailored language about the administration of $W-2$ in a thinly veiled reference to Milwaukee County that required it alone among the counties to establish a detailed plan for how $W-2$ was to be administered. Competitive bidding would be opened up to private sector vendors as well as county agencies that were rejected for ROFS (i.e., Milwaukee). Though one of the two goals of 
the $W-2$ program was privatization of the delivery system, due to ROFS that preceded the $C B P$ process, administration remained unchanged from $A F D C$ for a majority of counties.

It might have been expected that the State would peg agency compensation to specific performance measures. The 99 Group proposed that performance-based elements of the contract were to be based on "capitation" (Arrow, 1970) -- an idea 99 Group members borrowed from the managed-care model in health care where the State had successfully introduced managed competition in its purchase of health care for State employees and as well as the Medicaid population $(D W D, 2000)$. This imitation made sense from a human capital theoretic standpoint (Becker, 1993) as the return on investment could be elevated for such asset classes as the poor by not only improving their health, but also by educating them with relevant job skills. Under capitation, each $W-2$ agency would be paid a flat fee for administering the program over the first two years of the program. All costs of running the program, including cash payments to participants, would be drawn from that fee. If program costs exceeded the fees, the agency would make up the difference itself.

The capitation system of reimbursement gave public assistance administrators a financial stake in the outcomes they were producing. The more quickly they moved $W-2$ participants into unsubsidized, private sector jobs, the more money vendors would earn. This sort of arrangement, 99 Group members believed, focused vendors on outcomes -- namely employment for program participants -- rather than mandated inputs and procedures, as under the old $A F D C$ system. Importantly, if an agency could administer $W-2$ for less money than the State had allocated it, it got to keep part of the difference as profit and bonuses and thereby created an obvious incentive for $W-2$ agencies to hold down program costs by moving participants into un-subsidized, private-sector jobs.

The total amount disbursed by the State for the Contract 1 was $\$ 652$. The contract formula for sharing profits resulted in a total of $\$ 148.5$ million in profits and bonuses (22.8\% return on revenue). Contract 1 subsequently came under criticism from such parties as the Joint Committee of Finance $(J C F)$ the Legislative Audit Bureau $(L A B)$, and members of the legislature for two major reasons: (1) the excessive amounts of profits and bonuses earned by the agencies; and (2) the nature of the performance contract -- a capitated contract with an implicit incentive to actually withhold needed services. The criticism of excessive profits was particularly directed at two of the private sector agencies that replaced the Milwaukee county agency as the service provider - ESI and Maximus.

Senator Moore, an African-American serving Milwaukee whose constituent welfare recipients were also primarily African American, was very critical of the excessive profits, especially for-profit providers, that were selected to replace her county agency as the welfare provider. She felt that "the DWD had egg on its face for the profits that Maximus earned," and charged that these large, for-profit companies were "getting Wisconsin taxpayers' money." More forcefully, she also observed that "This is a plantation, and would-be activists are being paid to be the overseers" (Mead, 1999: 25; Misra, et al., 2003).

The second major criticism of Contract 1 concerned the capitation-based performance contract and revolved around the issue of whether welfare agencies would behave according to commercial, as opposed to social criteria in serving the needy. The Joint Committee on Finance stated that the new contract should not permit agencies to receive profits based on caseload reductions or reduced agency spending that were not directly attributable to placement of $W-2$ participants in un-subsidized employment. The $L A B(1999)$ recommended to the Legislature that the $D W D$ move to a "performance bonus model," where contracts would include a variety of performance standards that addressed both the quality and quantity of services provided.

In response to these criticisms, the $D W D$ (1999) promised that "For the next round of contracts, the Department will restrict the amounts of total profit available to agencies." It also pledged for future contracts that:

- contracts would require $W-2$ agencies to provide an array of services, with increased expectations for performance that will be quantitatively measured;

- profits would no longer be based on the difference between estimated budget and actual expenditures, but on specifically defined and measurable standards that reflect both the quality and the quantity of services delivered by the agencies; and

- the potential amount of profit would be capped at $7 \%$.

On May 19, 1999, the $D W D$ issued final rules and criteria for administering Contract 2. Under Contract 2, the $D W D$ specified that $W-2$ agencies would be required to meet six performance criteria. The total base budget for Contract 2 was $\$ 369.3$ million, down from $\$ 652$ million in Contract 1. The potential financial rewards (profits and bonuses) for meeting the base standards available in Contract 2 for all provider agencies would be $7 \%$, or $\$ 25.9$ million, of the total contract amount -- an amount significantly less than the $\$ 148.5$ million of bonuses in Contract 
1. Noteworthy, Contract 2 was crafted as part of Thompson's final budget as Governor of Wisconsin. Thompson then moved on to his role as Secretary of Health and Human Services in President Bush's Cabinet, where he was charged with undertaking national welfare reforms within the Federal government by replicating his efforts in Wisconsin.

With Thompson's departure to Washington and the election of a Democratic Governor, Jim Doyle, the budgetary dialog that surrounded $W-2$ became dramatically altered as Wisconsin entered Contract 3 . The definition of "performance-based contracting" continued to be expressed using specific performance criteria in Contract 3, albeit expanded from six criteria in Contract 2 to thirteen criteria in Contract 3 in response to continuing criticisms of the capitation basis by $J C F$ and $L A B$ as well as negative press coverage. Moreover, two criteria were specifically developed in response to significant fraudulent activity by agencies, mostly for-profit service vendors in Milwaukee County -- ESI and Maximus (Milwaukee Times, 2001).

In May of 2001, the DWD issued the final rules for Contract 3. Agencies that met the base standard for all thirteen criteria once more received two benefits: (1) a portion of the performance bonus for Contract 3; and (2) guaranteed selection as a provider agency for Contract 4 . The potential profits and performance bonus amounts for Contract 3 were reduced to $\$ 23.6$ million from $\$ 25.9$ million in Contract 2. However, a major funding change in Contract 3 was that the profit/bonus incentive was no longer directly tied to the contract, but would instead be determined within the State's biennial budgetary process. Subsequently, Act 33 (the biennial budget) provided no funding for profits and performance bonuses for Contract 3 (LAB, 2005a). Governor Doyle was officially on record for providing the same $7 \%$ of base contract incentive as did his predecessor, but actually cut funding for providers.

The only substantive issue in Contracts 4 and 5 revolved around a continuing reduction in contract funding as the Democratic Governor continued his mastery of the "budgetary game," while cutting back the Republican-created $W$-2 welfare program to which Doyle bore no allegiance. Profits and bonuses were never granted under these contracts Unlike Contract 3, however, the $D W D$ did not even attempt to request funding for profits and bonuses in its Contract 4 budget under Act 25 (the new biennial budget), perhaps because there was little hope that funding for profits or bonuses would be available $(L A B, 2005 \mathrm{a})$. More importantly, however, for the first time under $W-2$, $D W D$ did not even receive the full amount of the base budget amount. DWD was granted only $\$ 257$ million of the initial \$286 million contract, and would have to return to the $J C F$ for the remaining \$29 million under the new Democratic regime's rules of the budgetary game. $D W D$ was fighting just to hit its breakeven point.

Ironically, the decreased funding came under criticism from $L A B$ (2005b). The $L A B$ cautioned that in $W$-2's first several years, funding levels greatly exceeded program needs, largely because caseloads initially fell much faster than had been anticipated. In contrast, in more recent years, caseloads had increased, and yet contract funding had still been ratcheted down, with agencies repeatedly requesting supplemental funds to better serve welfare recipients. The $L A B$ concluded that the $\$ 257$ million actually allocated to the agencies under Contract 4 was insufficient to serve recipients effectively. In particular, Milwaukee County once more arose as especially problematic, as much of the $\$ 29$ million was withheld from this county because of the fraud that had been committed there even though the poor had not even received the original funds diverted by ESI and Maximus. Despite $L A B$ 's efforts, the total amount awarded for Contract 5 was $\$ 224.5$ million, not even at Contract 4 's $\$ 257$ million level which $L A B$ deemed inadequate, with potential profits and bonuses of $\$ 0$. And so, using the monetizing, calculative regime of $W-2$, Wisconsin had indeed effected a dramatic reduction in its welfare budget from its initial $\$ 652$ million, and number of recipients from more than 300,000 to 10,000. Specifically in terms of W-2's initial financial impact in Milwaukee, the Employment and Training Institute (1996: iii-iv) found for example that: "1) Children of disabled parents will be removed from AFDC and W-2 and have their benefits cut by 60 percent, saving [Wisconsin] \$10 million annually; 2) Relative foster care families will be removed from AFDC and W-2 and most cases will experience benefit reductions which will save \$1 million annually; 3) Imposing strictrer financial sanctions for refusal to participate in work or child support programs will likely reduce the caseload by at least 5000 to 6000 cases; 4) The cap on assistance payments regardless of family size will effectively reduce benefits by as much as half [ $\$ 6000$ per year] to the largest families; and 5) Most working families on AFDC will be removed from public assistance."

As Wisconsin's W-2 equivalent became applied by the federal government under the 1996 Personal Responsibility and Work Opportunity Act under DHHS Secretary Thompson's leadership, ever more of its financial burden became shifted to the states (Gilbert, 2009). In response, many states, including Wisconsin sought to reduce its W-2 expenditures by hiring such consulting firms as Public Consulting Group to aggressively shift people from the welfare rolls to disability that is $100 \%$ funded by the federal government. For example, by screening likely candidates using state welfare rolls, helping individuals complete the necessary documentation and even scheduling medical appointments where necessary, they redefined them from the "needy" to the "disabled" 
(Burkhauser \& Daly, 2011; National Public Radio, 2013), a strategy that is expected to cost tens of billions of US tax dollars per year (Wall Street Journal, 2013a).

\section{Converting Societal 'Liabilities' into 'Productive Assets'}

The cost of Wisconsin's welfare program, as well as the political need to demonstrate action, was used to spark the effort to fundamentally change the existing welfare system. Wisconsin's Republican Governor, Tommy Thompson sought and received permission from the Federal government to experiment with the predecessor, $A F D C$ program and eventually implement $W-2$. Consistent with a neo liberal ideology, and widespread application of NPM/PPP, financialization of government and public/private partnerships, the focus of $W-2$ involved: 1) the development of a market-based delivery system, and 2) the use of performance-based contracting. Each contract period saw further contentious social negotiation of W-2's provisions. Lurking beneath these 10 years of renegotiation, statement and re-statement of the rules of the budgetary game, were the dramatic reduction in resources committed to welfare that was made to appear to be a mere matter of auto-regulatory calculation based upon a capitation framework (Arrow, 1970) and a human asset-based ideology (Becker, 1993). In a sense, the technical details politically obfuscated the social dynamics of the reform effort (Hausermann \& Palier, 2008: 562; Soss et al., 2011).

While some semblance of comprehensive reform was achieved within Milwaukee county, and only for Contracts 1 and to a lesser extent 2, the discourse surrounding it remained that of comprehensive reform. In turn, Jim Doyle, a Democrat, was elected Governor and had no vested interest in supporting a Republican agenda, other than enjoy the husbanding of financial resources it occasioned. During his office, Doyle continued to nominally support the generally popular (except in Milwaukee) $W-2$ program, but de-capitated the link to Wisconsin's managed healthcare policy paradigm, and strategically linked it with other facets of the State's budgetary policy paradigm, Acts 25 and 33, and systematically: emasculated $D W D$ 's power as a budgetary player, eliminated incentive bonuses, and ratcheted down $W-2$ 's budget over Contracts 3-5. Thus, the distinctions between: the political and the economic, the public and the private, the competitive and the monopolistic, and performance contracting and cost plus reimbursement were rendered problematic. In a sense, the calculative regime of $W-2$ augmented with a rhetoric of social justice and empowering the poor with work, was used as a symbolic gesture to justify what were largely political and economic decisions (Cox, 1998). As welfare recipients were, in turn, rendered into "monetized persons."

While we focused our attention on exploring the infra-structural properties of $W$-2 rather than its effects on welfare recipients (see DeParle, 2004; Haskins, 1999; Heinrich \& Choi, 2007; Hennessy, 2005; Mead, 2004; Misra et al., 2003; Watkins-Hayes, 2009; Wiseman, 1999, for such analyses) it is worth noting that in reducing Wisconsin's welfare budget from $\$ 652$ million to $\$ 224.5$ million, it also reduced the number of entitlement recipients from 300,000 in 1986 to under 10,000 at the end of Contract 5 -- mostly single mothers and their children, and in Milwaukee predominantly single African-American mothers. More specifically, in moving from county agencies to private vendors in Milwaukee, it is likely that the workforce of street-level welfare offices changed with respect to racial mix; here, Watkins-Hayes (2009) found that welfare workers of color not only identified with their clients, but also applied welfare regulations through racial, class and gendered interpretive schemas. In moving to private sector vendors in Milwaukee, it is likely that the workforce changed, thereby altering how funding was applied (Fletcher, 2011). Moreover, for the first two contract periods, and the only contracts for which bonuses were eventually to be offered, counties could re-direct the bonuses earned, for example, to funding other community services to low income residents, while private vendors serving Milwaukee could keep at least a portion of them as profits $(L A B, 1999)$; thus, fewer funds were available to serving the poor in Milwaukee. Further, the only vendors that were discovered as having committed fraud, thereby further diverting resources from serving the poor, were private vendors operating in Milwaukee County (ESI and Maximus); thus, less funding was available to serving the poor in Milwaukee. And finally, for Contract 5, a majority of the $\$ 32.5$ million of the original budget that was withheld from being allocated to $D W D$ was to have been disbursed to Milwaukee County because of the fraud that had been committed in this county by its private sector providers. Within Milwaukee, a significant majority of the caseload is comprised of single African American mothers with dependent children (e.g., DeParle, 2004; Mead, 2004). Hence, the variant of $W-2$, the delivery workforce, and the funds that were applied to Milwaukee, were systematically different from the rest of the state for a caseload that was predominantly comprised of single African American mothers (for discussion of the politicalization of welfare in terms of class, race and gender, see Soss, et al., 2001; Watkins-Hayes, 2009; Hausermann \& Palier, 2008). It appears that the variant of $W-2$ that was applied to Milwaukee was de facto racialized (see also Soss et al., 2011; Misra et al., 2003; Quadagno, 1994).

While county and welfare agency officials continually criticized $W-2$ using the rhetoric of its impairing their ability to serve the needy, they also had a vested interest in combating budget reductions in order to preserve their 
own positions. However, while critical of $W-2$ for its excessive bonuses under Contracts 1 and 2 , the constitutionally independent $L A B$ cautioned that Contracts 3, 4 and especially 5 risked inadequately serving the State's poor. As the U.S. and countries throughout the world continue to experience financial strain and governments devote more money toward public and private sector bailouts, one can but speculate about the fortunes of the poor, with Herbst (2008; see also Huber \& Stephens, 2001; Institute for Women's Policy Research, 2011), for example, finding that the positive effects generated by policy reforms may not be as strong in a weak economy. Supporting this position, faced with $\$ 500$ million deficit in Wisconsin's current budget, and projecting a $\$ 5$ billion shortfall in its two year budget cycle that ended June, 2011, Governor Doyle asked all State agencies including welfare to reduce their budgets by 10\% (Wall Street Journal, 11/22/2008: A3).

The effects of this reduction is also documented in a Milwaukee Journal Sentinel (2008; see also Pierson, 2001; Rogers-Dillon \& Skrentny, 1999) article commenting that,

The chaos that erupted outside Milwaukee County's main welfare office Monday over disaster-related food aid had more to do with a weak economy and crushing poverty in parts of this community than the devastating floods that swept through the state earlier this month, local government and food relief officials said. About 3,000 people turned out for the assistance beginning at $3 \mathrm{a} . \mathrm{m}$. Monday, creating a line that stretched several blocks."The food crisis in Milwaukee and throughout the United States is worse than many of us have realized," said Milwaukee Common Council President Willie Hines, who with other elected officials called on the community to support local food pantries."We expect long lines for free food in Third World countries," Hines said. "We don't expect a line of 2,500 people waiting for food vouchers in Milwaukee."

Indeed, the U.S. Department of Agriculture has estimated that the number of Wisconsin's poor relying on food stamps increased by $31.3 \%$ between Spring 2008 and 2009, among the largest state gains in the U.S. (International Committee of the Fourth International, 2009).

The problems attendant to $W-2$ are likely to have also been exacerbated by the subprime mortgage debacle that came about, at least in part, as a consequence of general acceptance of a neo liberal ideology and the financialization of the American economy (Davis, 2009; Campbell, 2010; Fligstein \& Goldstein, 2010; Krippner, $2005,2010)$. The linkage begins with the emerging concept of asset-based welfare; herein, focus is placed upon building up the asset base, especially home ownership of the poor, rather than augmenting their basic income; this increase in stock of capital will in turn increase the poor's well being, in essence serving as a longer term preventative of poverty (Ackerman \& Alstott, 1999; Moser \& Dani, 2008). The roots of applying this form of welfare in the U.S. (for application in the U.K., see Gregory \& Drakeford, 2006) go back to the rise of asset-based welfare with President Lyndon Johnson's Great. In order to not further increase the federal deficit during the Viet Nam war and still accomplish the administration's goals, Fannie Mae was reorganized as a quasi private organization to issue mortgages, and Freddie Mac and Ginnie Mae created to, respectively, compete with Fannie Mae and insure the mortgages issued by a long process that is beyond the scope of this paper (for exceptional analyses, see Campbell, 2010; Fligstein \& Goldstein, 2010; Krippner, 2010). Eventually the financial instrument of mortgage-backed securities was developed from this base and sub-prime lending practices evolved in which the poor obtained mortgages (wherein the "assets" that had been borne of $W-2$ themselves acquired assets) that were eventually bought by Fannie Mae and Freddie Mac and that, consistent with a prevalent neo liberal ideology, went unregulated until the market collapsed. The effects of these practices and collapse were especially telling, again in Milwaukee, in terms of foreclosures on the again the poor, and again especially on the African-American community, as observed by the City of Milwaukee (2008: 1):

For the first nine months of 2008, foreclosure filings in City of Milwaukee were up 35\% compared to the same period in 2007...In Milwaukee, foreclosures and the related issues of subprime and predatory lending disproportionately impacted Milwaukee's poorest neighborhoods and low income and minority families. There were over 17,800 subprime loans originated in Milwaukee County in 2005 and 2006, totaling over \$1.7 billion. In 2006, 59\% of all of the mortgages issued in Milwaukee's Community Development Block Grant Area were either subprime or high interest rate mortgages. In 2006, over 2/3 (69\%) of African American borrowers obtained high cost mortgages compared to less than $1 / 3(30 \%)$ of whites. ...Home equity, which is the single largest source of wealth building for most low and moderate income families, is being erased. 
It appears that the marginally employed poor under $W-2$ will be the first to be laid off and the first to lose their homes to foreclosure -- a speculation supported by the results of a study by Hennessey (2005; Hofferth, 2002; Hausermann \& Palier, 2008) who found that low income, single-parent, female-headed families did not fare well under work programs if they had been off welfare for more than two years. Indeed, according to the U.S. Census Bureau (2010), "the poverty rate in 2009 (14.3 percent) was the highest poverty rate since 1994 ... and the number of people in poverty in 2009 ( 43.6 million) was the largest number in the 51 years for which poverty estimates have been published." It may well be that the tensile strength of the Wisconsin's welfare safety net may not be sufficient to catch the recently, and marginally employed poor under $W-2$ as they continue to face layoffs and loss of their homes.

\section{Concluding Remarks}

The issue unresolved in our analysis of W-2 is whether such auto-regulatory mechanisms as performance contracting and the market-based delivery of welfare services can efficaciously foster meaningful governmental reform. Exploring this theme, March and Olsen (1983: 292) observed that:

Governance is an interpretation of life and an affirmation of legitimate values and institutions. . . It provides symbolic and ritual confirmation of the possibility of meaningful individual and collective action. The argument is not that symbols [such asW-2] are important to politics, although they certainly are. Rather, the argument is the reverse -- that politics are important to symbols, that a primary contribution of politics to life is in the development of meaning. ... They are heavily intertwined, and discussion of primacy may obscure that fact.

Similarly, Wildavsky (1979: 7-12) reasoned that shared living experiences: reinforce or legitimate social relations; shape individual preferences; and, most importantly, create societal values, which are then applied to interpreting objects and events. It follows that important decisions, such as Wisconsin's decision to reform its welfare service delivery program, are simultaneously choices of culture that entail shared values legitimating different patterns of social practice. The purposes institutions create are expressed by such social practices as market-based delivery of welfare services and performance-based contracts which serve as a way of constituting power relations in the sense that they are mitigated by social interaction. Consequently, administrative practices in the public sector may involve not only legitimizing the actions of governmental units seeking reform, but also, and perhaps more importantly, supporting a political structure that operates so as to serve the immediate self-interest of powerful interest groups.

Viewed as a form of language, such calculative practices as performance contracting may be selectively deployed by the state not only to reflect and hopefully improve underlying economic conditions, but to create public values, acquiescence, and support (Hetling \& McDermott, 2008). More specifically, Edelman (1977: 58) observed:

Language is always an intrinsic part of some particular social situation; it is never an independent instrument or simply a tool for description. By naively perceiving it as a tool, we mask its profound part in creating social relationships and in evoking the roles and the "selves" of those involved in the relationships.

Consent of the governed comes about not from the conscious acceptance of rules of procedure, but at differing times, as acquiescence to, taking for granted, resisting, and seeking to transform the codified provisions of regulations, thus at once creating, supporting, and continually modifying a hierarchical relationship between the governed and the state. Although cloaked in the appearance of objectivity and neutrality, innovative calculative regimes codified within reforms are ultimately directed toward establishing and maintaining hierarchies of authority and status. Thus, not only was the political milieu of Wisconsin important to shaping $W-2$, but equally, the calculative regime of $W-2$ played a prominent role in shaping Wisconsin's and indeed the nation's politics which continue to the present, with significant reductions in the food stamp program (Washington Post, 2013).

At a more general level, Giddens (1984) described the reciprocal, interdependent relationship between the social and the structural in advancing his pivotal construct of structuration. Within the structuration account, focus is placed on examining the production, transformation, reproduction, and dissolution of social institutions by specifically incorporating both the concepts of structure (such as the codes, rules and standard operating procedures that, for example, lie within the provisions of W-2) that influence and are influenced by social actions of organizational actors in their day-to-day activities. Here, the social and the structural are intertwined with one another such that structures are understood to inhere in social relations that are at once constrained and promoted by organizational routines. According to this perspective, structure, broadly construed, influences the social interactions, even the sanctioned language forms used (e.g., eligibility technicians vs. employment planners), 
taking place within organizations, which are nevertheless transformed through the social actions of individuals, who, in applying facets of formal organizational structure, subtly modify them over time. Thus, performance contracting and market-based delivery, or even their founding elements of capitation (Arrow, 1970) and a human asset ideology (Becker, 1993), cannot be fully understood and evaluated apart from the social/political context within which they are implemented, that each plays a very active, dynamic role in constituting the other.

It may well be that the auto-regulatory mechanism embodied by W-2 was implemented, at least in part, in order to avoid face to face confrontations and allow politicians and administatrors to state to welfare recipients that the negative impact on their lives was not politicians' fault, but the system's. However, if the essence of politicians and administrators lies within the system, and the essence of the system lies within politicians and administrators in the sense that they are reciprocally interdependent, then they cannot make this claim for they are the system and the system is them. Their personal accountability remains.

\section{Acknowledgements}

We wish to thank the Deloitte \& Touche Foundation for its support for this ongoing program of research

\section{References}

Ackerman, B., \& Alstott, A. (1999). The Stakeholder Society. New Haven, CT.: Yale University Press.

Amable, B. (2011). Morals and Politics in the Ideology of Neo-liberalism. Socio-Economic Review, 9(1), 3-30. http://dx.doi.org/10.1093/ser/mwq015

Arrow, K. (1970). Social Choice and Individual Values (2nd ed.). New Haven, CT: Yale University Press.

Becker, G. (1993). Human Capital: A Theoretical and Empirical Analysis, with Special Reference to Education (3rd ed.). Chicago: University of Chicago Press. http://dx.doi.org/10.7208/chicago/9780226041223.001.000 1

Burkhauser, R., \& Daly, M. (2011). Declining Work and Welfare of People with Disabilities: What Went Wrong and a Strategy for Change. New York: AEI Press.

Campbell, J. L. (2010). Neoliberalism in Crisis: Regulatory Roots of the U.S. Financial Meltdown. In M. Lounsbury, \& P. Hirsch (Eds.), Markets on Trial: The Economic Sociology of the U.S. Financial Crisis (pp. 65-101). Research in the Sociology of Organizations. http://dx.doi.org/10.1108/S0733-558X(2010)00 $\underline{0030 \mathrm{~B} 007}$

Chwastaik, M. (2001). Taming the Untameable: Planning, Programming and Budgeting and the Normalization of $\begin{array}{llll}\text { War. Accounting, Society, } & \text { 26, }\end{array}$ http://dx.doi.org/10.1016/S0361-3682(01)00010-1

City of Milwaukee. (2008). Neighborhood Stabilization Program (NSP): Substantial Amendment to the Consolidated Plan and the 2008 Annual Action Plan. Retrieved June 14, 2012, from http://city.milwaukee.gov/ImageLibrary/User/jsteve/NSP_Executive_Summary.pdf

Clarke, J. (2004). Dissolving the Public Realm? The Logics and Limits of Neo-liberalism. Journal of Social Policy, 33(1), 27-48. http://dx.doi.org/10.1017/S0047279403007244

Cooper, D., \& Hopper, T. (2007). Critical Theorizing in Management Accounting Research. In C. Chapman, A. G. Hopwood, \& M. Shields (Eds.), Handbook of Management Accounting Research. Elsevier, U. K.

Covaleski, M., \& Dirsmith, M. (1991). The Management of Legitimacy and Politics in Public Sector Administration. Journal of Accounting and Public Policy, (Summer), 135-156. http://dx.doi.org/10.1016/0278-4254(91)90009-9

Covaleski, M., \& Dirsmith, M. (2005). Institutional Destabilization and the New Public Management: The Case of Tax Incremental Financing. International Journal of Public Policy, 1(1/2), 122-147. http://dx.doi.org/10.1504/IJPP.2005.007799

Covaleski, M., Dirsmith, M., \& Weiss, J. (2012). The Mesodomain of Welfare Reform: Re-negotiating the Order of Economic Inequality. Studies in Symbolic Interaction, 39, 3-49. http://dx.doi.org/10.1108/S0 163-2396(2012)0000039003

Cox, R. (1998). The Consequences of Welfare Reform: How Conceptualizations of Social Rights Are Changing. Journal of Social Policy, 27(1), 1-16. http://dx.doi.org/10.1017/S0047279497005163

Crouch, C. (2011). The Strange Non-Death of Neo-Liberalism. Cambridge, UK: Polity Press. 
Davis, G. F. (2009). Managed by Markets: How Finance Re-shaped America. New York: Oxford University Press.

Denhardt, M., \& Baker, L. (2007). Five Great Issues in Organization Theory. In Rabin, Hildreth, \& Miller (Eds.), Handbook of Public Administration (pp. 121-148). New York, NY: Taylor \& Francis.

DeParle, J. (2004). American Dream: Three Women, Ten Kids, and a Nation's Drive to End Welfare. New York: Viking.

Department of Workforce Development. (1999). Response Letter to the Legislative Audit Bureau. Madison, WI: State of Wisconsin.

Department of Workforce Development. (2000). Resource Guide to Welfare Reform. Madison, WI: State of Wisconsin.

Dunleavy, P. H., Margetts, S., Bastow, S., \& Tinkler, J. (2006). New Public Management is Dead - Long Live Digital Era Governance. Journal of Public Administration Research and Theory, 16, 467-494. http://dx.doi.org/10.1093/jopart/mui057

Edelman, J. M. (1977). Political Language: Words That Succeed and Policies That Fail. New York: Academic Press.

Employment \& Training Institute. (1996). Financial Impact of W-2 and Related Welfare Reform Initiatives on Milwaukee County AFDC Cases. Retrieved from http://www4.uwm.edu/eti/reprints/AFDCtoW2.pdf

English, L. M., \& Skellern, M. (2007). Public-Private Partnerships and Public Sector Management Reform: A Comparative Perspective. International Journal of Public Policy, 1, 1-21. http://dx.doi.org/10.1504/IJPP.2005.009089

Epstein, G. A. (2005). Financialization and the World Economy. North Hampton, MA: Edward Elger.

Espelend, W., \& Stevens, M. (1998). Commensuration as a Social Process. American Sociological Review, 94, 313-343. http://dx.doi.org/10.1146/annurev.soc.24.1.313

Ferraro, F., Pfeffer, J., \& Sutton, R. I. (2005). Economics Language and Assumptions: How Theories Can Become Self-Fulfilling. Academy of Management Review, 30, 8-24. http://dx.doi.org/10.5465/AMR.2005.15281412

Finlayson, A. (2009). Financialisation, Financial Literacy and Asset-based Welfare. The British Journal of Politics and International Relations, 11, 400-421. http://dx.doi.org/10.1111/j.1467-856X.2009.00378.x

Fletcher, D. (2011). Welfare Reform, Jobcentre Plus and the Street-level Bureaucracy: Towards Inconsistent and Discriminatory Welfare for Severely Disadvantaged Groups. Social Policy and Society, 10(4), 44-458. http://dx.doi.org/10.1017/S1474746411000200

Fligstein, N., \& Goldstein, A. (2010). The Anatomy of the Mortgage Securitization Crisis. In M. Lounsbury, \& P. Hirsch (Eds.), Markets on Trial: The Economic Sociology of the U.S. Financial Crisis, Research in the Sociology of Organizations (Vol. 30A, pp. 29-70).

Foster, J. B. (2007). The Financialisation of Capitalism. Monthly Review, 58(11), 1-12.

Giddens, A. (1984). The Construction of Society. Cambridge: Polity.

Gilbert, N. (2009). U.S. Welfare Reform: Rewriting the Social Contract. Journal of Social Policy, 38(3), 383-399. http://dx.doi.org/10.1017/S0047279409003043

Gregory, L., \& Drakeford, M. (2006). Social Work, Asset-based Welfare and the Child Trust Fund. British Journal of Social Work, 36(1), 149-157. http://dx.doi.org/10.1093/bjsw/bch382

Haskins, R. (1999). Foreword. W-2 Research Assessment and Direction Conference. Racine, WI (December 10), 3-5.

Hausermann, S., \& Palier, B. (2008). The Politics of Employment-Friendly Welfare Reforms in Post-Industrial Economies. Socio-Economic Review, 6(3), 559-586. http://dx.doi.org/10.1093/ser/mwn011

Hays, S. P. (1959). Conservation and the Gospel of Efficiency. Cambridge, MA: Harvard University Press.

Heclo, H. (1986). General Welfare and Two American Political Traditions. Political Science Quarterly, 101, 182-203. http://dx.doi.org/10.2307/2151387

Heinrich, C., \& Choi, Y. (2007). Performance-Based Contracting in Social Welfare Programs. The American Review of Public Administration, 37, 409-435. http://dx.doi.org/10.1177/0275074006297553 
Hennessy, J. (2005). Welfare Work, and Family Well-eing: A Comparative Analysis of Welfare Employment Status for Single Female-Headed Families Post TANF. Sociological Perspectives, 48, 77-104. http://dx.doi.org/10.1525/sop.2005.48.1.77

Herbst, C. M. (2008). Do Social Policy Reforms Have Different Impacts on Employment and Welfare Use as Economic Conditions Change? Journal of Policy Analysis and Management, 27, 867-894. http://dx.doi.org/10.1002/pam.20380

Hettling, A., \& McDermott, M. (2008). Judging a Book By Its Cover: Did Perceptions of the 1996 US Welfare Reforms Affect Public Support For Spending on the Poor? Journal of Social Policy, 37(3), 471-487. http://dx.doi.org/10.1017/S0047279408002006

Hofferth, S. (2002). Did Welfare Reform Work? Implications for 2002 and Beyond. Contexts, 1, 45-51. http://dx.doi.org/10.1525/ctx.2002.1.1.45

Hood, C., \& Peters, G. (2004). The Middle Aging of New Public Management: Into the Age of Paradox. Journal of Public Administration Research and Theory, 14(3), 267-282. http://dx.doi.org/10.1093/jopart/muh019

Hood. C. (1995). The 'New Public Management' in the 1980s: Variations on a Theme. Accounting, Organizations and Society, 20, 93-109. http://dx.doi.org/10.1016/0361-3682(93)E0001-W

Howard, C. (1997). The Hidden Welfare State: Tax Expenditures and Social Policy in the 1997 United States. Princeton, N.J.: Princeton University.

Huber, E., \& Stephens, J. D. (2001). Development and Crisis of the Welfare State: Parties and Policies in Global Markets. University of Chicago Press, Chicago. http://dx.doi.org/10.7208/chicago/9780226356495.001.0001

Institute for Women's Policy Research. (2011). Women, Poverty, and Economic Insecurity in Wisconsin and the Milwaukee-Waukesha-West Allis MSA. Retrieved from http://www.google.com/url?sa=t\&rct=j\&q=\&esrc= $\mathrm{s} \&$ source=web\&cd=10\&ved=0CGcQFjAJ\&url=http\%3A\%2F\%2Fwww.iwpr.org\%2Fpublications $\% 2$

International Committee of the Fourth International. (2009). One in Nine Americans Use Food Stamps, August 20, 1. Retrieved from http://www.wsws,org/articles/2009/food

Katz, M. (2001). The Price of Citizenship: Reforming the American Welfare State. New York: Metropolitan Books.

Kettl, D. (2002a). The Transformation of Governance. Baltimore, MD: John Hopkins University Press

Kettl, D. (2002b). Managing Indirect Government. In L. Salamon (Ed.), The Tools Of Government: A Guide to the New Governance. New York, NY: Oxford University Press.

King, D. S. (1992). The Establishment of Work-Welfare Programs in the United States and Britain: Politics, Ideas and Institutions. In S. Steinmo, K. Thelen, \& F. Longstreth (Eds.), Structuring Politics: Historical Institutionalism in Comparative Analysis (pp. 217-250). Cambridge University Press, Cambridge. $\mathrm{http}: / / \mathrm{dx}$. doi.org/10.1017/CBO9780511528125.009

Kolko, G. (1963). The Triumph of Conservatism. Chicago: Quadrangle Books.

Krippner, G. R. (2010). The Political Economy of Financial Exuberance. In M. Lounsbury, \& P. Hirsch (Eds.), Markets on Trial: The Economic Sociology of the U.S. Financial Crisis, Research in the Sociology of Organizations (pp. 141-173). http://dx.doi.org/10.1108/S0733-558X(2010)000030B009

Krippner, G. R. (2005). The Financialization of the American Economy. Socio Economic Review, 3, 173-208. http://dx.doi.org/10.1093/SER/mwi008

Larson, M. S. (1977). The Rise of Professionalism: A Sociological Analysis. Berkeley: University of California Press.

Legislative Audit Bureau. (2005a). Letter Report: Financial Management of Selected W-2 Agencies. Madison, WI: State of Wisconsin.

Legislative Audit Bureau. (2005b). An Evaluation of Wisconsin Works (W-2) Program. Madison, WI: State of Wisconsin.

Legislative Audit Bureau. (1999). A Review of Wisconsin Works (W-2) Program. Madison, WI: State of Wisconsin.

March, J. G., \& Olsen, J. (1983). Organizing Political Life: What Administrative Reorganization Tells Us About American Life. American Political Science Review, 77, 281-296. http://dx.doi.org/10.2307/1958916 
Massing, M. (1999). The End Of Welfare: An Outside Perspective On What's Right And What's Wrong With W-2. Isthmus, (October 22), 9-11.

Mathiasen, D. G. (1997). The New Public Management and Its Critics. Advances in International Comparative Management: International Perspectives in the New Public Management, (Supplement 3), 273-296.

Maxwell, R. S. (1956). LaFollette and the Rise of the Progressives in Wisconsin. Madison, WI: The State Historical Society of Wisconsin.

McCaffery, J. L. (1987). The Development of Public Budgeting In the United States. In R. C. Chandler (Ed.), A Centennial History of the American Administrative State (pp. 345-373). New York, NY: Macmillian.

McNichols, P., \& Windsor, C. (2011). Can the Financialised Atmosphere be Effectively Regulated and Accounted For? Accounting, Auditing and Accountability Journal, 24(8), 1071-1096. http://dx.doi.org/10.1108/09613671111184760

Mead, L. M. (1999). The Decline of Welfare in Wisconsin. Journal of Public Administration Research and Theory, 9, 597-622. http://dx.doi.org/10.1093/oxfordjournals.jpart.a024424

Mead, L. M. (2004). Government Matters: Welfare Reform in Wisconsin. Princeton, NJ: Princeton University Press.

Meyers, M. (2003). Families That Work: Policies for Reconciling Parenthood and Employment. New York: Russell Sage Foundation.

Miller, P. (1992). Accounting and Objectivity: The Invention of Calculating Selves and Calculable Spaces. Annals of Scholarship, 9, 61-86.

Milward, B. H. (1996). Symposium on the Hollow State: Capacity, Control and Performance in Inter-Organizational Settings. Journal of Public Administration Research and Theory, 6, 193-195. http://dx.doi.org/10.1093/oxfordjournals.jpart.a024306

Milwaukee Journal Sentinel. (2008). Food Relief Line Grows Long, Tense: Frustration Rises, Officials Caught Off-Guard As Thousands Turn Out for Flood Assistance. (June 24), B1.

Milwaukee Times. (2001). Moore Responds To Financial Audit of Wisconsin Works Program. (March 1), B1.

Misra, J., Moller, S., \& Karides, M. (2003). Envisioning Dependency: Changing Media Depictions of Welfare in the $20^{\text {th }}$ Century. Social Problems, 50, 482-504. http://dx.doi.org/10.1525/sp.2003.50.4.482

Moser, C., \& Dani, A. A. (2008). Assets, Livelihoods and Social Policy. Washington, D.C.: World Bank Publications. http://dx.doi.org/10.1596/978-0-8213-6995-1

Mudge, S. (2000). What Is Neo-Liberalism? Socio-Economic Review, 6(4), 703-731. http://dx.doi.org/10.1093/ser/mwn016

Murray, C. (1984). Losing Ground: American Social Policy 1950-1980. New York: Basic Books.

National Public Radio. (2013). All Things Considered: Moving People from Welfare to Disability Rolls Is a Profitable, Full Time Job.

Osborne, D., \& Gaebler, T. (1992). Reinventing Government. New York, NY: Addison-Wesley.

Pierson, P. (2001). Coping With Permanent Austerity: Welfare State Restructuring In Affluent Democracies. In P. Pierson (Ed.), The New Politics of the Welfare State (pp. 410-500). Oxford: Oxford University Press. http://dx.doi.org/10.1093/0198297564.003.0014

Piven, F. F., \& Cloward, R. A. (1993). Regulating the Poor: The Functions of Public Welfare. Vintage Books, NY.

Preston, A., Chua, W., \& Neu, D. (1997). The Diagnosis-Related Group Prospective Payment System and the Problem of Government Rationing Health Care to the Elderly. Accounting, Organizations and Society, 22, 147-164. http://dx.doi.org/10.1016/S0361-3682(96)00011-6

Prizza, R. (2003). An International Perspective of Privatization: The Need to Balance Economic and Social Performance. American Review of Public Administration, 33, 316-33. http://dx.doi.org/10.1177/0275074003252072

Quadagno, J. S. (1994). The Color of Welfare: How Racism Undermined The War on Poverty. Oxford: Oxford University Press.

Riccucci, N. (2005). How Management Matters: Street-Level Bureaucrats and Welfare Reform. Washington, DC: Georgetown University Press. 
Rogers-Dillon, R., \& Skrentny, J. (1999). Administering Success: The Legitimacy Imperative and the Implementation of Welfare Reform. Social Problems, 46, 13-29. http://dx.doi.org/10.2307/3097159

Schiesl, M. (1977). The Politics of Efficiency. Berkeley, CA: University of California.

Shurkin, J. (2006). Broken Genius: The Rise and Fall of William Shockley, Creator of the Electronic Age. New York: Palgrave MacMillan.

Simmel, G. (1990). The Philosophy of Money. London: Rutledge.

Simon, H. A. (1947). Administrative Behavior. New York, NY: MacMillan.

Soss, J., Fording, R., \& Schram, S. (2011). Disciplining the Poor: Neoliberal Paternalism and the Persistent Power of Race. Chicago: University of Chicago Press.

Statistics, Canada. (2007). Government Transfer Payments to Persons. Ottawa, Canada: Statistics Canada.

Suddaby, R. (2010). Challenges for Institutional Theory. Journal of Management Inquiry, 19, 14-20.

T. D. Bank Financial Group. (2005). From Welfare to Work In Ontario: Still the Road Less Traveled. Ontario, Canada: T.D. Bank Financial Group.

U.S. Census Bureau. (2010). U.S. Census. Retrieved from http://www.census.gov/

U.S. Department of Health and Human Services. (2009). Cohabitation and Marriage Rules in State TANF Programs. Retrieved from http://aspe.hhs.gov/hsp/09/CohabitationMarriageRules

United Kingdom Department of Works and Pensions. (2011). Retrieved from http://www.dwp.gov.uk/

Wall Street Journal. (2006). In Poverty Tactics, an Old Debate: Who Is At Fault? June 15: A1, A10.

Wall Street Journal. (2008). Midwest States Cut Spending in a Hurry as Region's Economy Deteriorates. Nov. 22: A3.

Wall Street Journal. (2013). Workers Stuck in Disability Stunt Economic Recovery. April, A1, A16.

Washington Post. (2012). Wisconsin's Gov. Scott Walker Victory Deals Blow to Unions. June 6: A1.

Washington Post. (2013). Retrieved from http://www.washingtonpost.com/politics/families-receive-5-percentless-in-food-stamps/2013/11/01/71e20d4e-4314-11e3-8b74-d89d714ca4dd_stor

Watkins-Hayes, C. (2009). Race-Ing the Bootstrap Climb: Black and Latino Bureaucrats in Post-Reform Welfare Offices. Social Problems, 56, 285-310.

Wildavsky, A. B. (1975). Budgeting: A Comparative Theory of Budgeting Processes. Boston: Little Brown.

Wildavsky, A. B. (1979). Speaking Truth to Power: The Art and Craft of Policy Analysis. Boston: Little Brown.

Wilson, W. (1956). The Executive. In Congressional Government: A Study in American Politics (pp. 163-192). New York: Meridian Books.

Wisconsin State Journal. (2001). Germany Looks To W-2 For Guidance: What About Wisconsin's Welfare Program Will Work In Hessen? (September 2), B1, B6, B7.

Wiseman, M. (1999). In Midst of Reform: Wisconsin In 1997. ANF Discussion Paper 99-03 (June).

\section{Copyrights}

Copyright for this article is retained by the author(s), with first publication rights granted to the journal.

This is an open-access article distributed under the terms and conditions of the Creative Commons Attribution license (http://creativecommons.org/licenses/by/3.0/). 